\title{
Population genetic structure of the ascidian Styela rustica at Kongsfjorden, Svalbard, Arctic
}

\author{
Milagros Demarchi ${ }^{\mathrm{a}, \mathrm{b}}$, Marina Chiappero ${ }^{\mathrm{b}}$, Jürgen Laudien ${ }^{\mathrm{c}}$, Ricardo Sahade ${ }^{\mathrm{a}, *}$ \\ a Ecología Marina, Facultad de Ciencias Exactas Físicas y Naturales, Universidad Nacional de Córdoba, Av. Vélez Sársfield 299, CP 5000, Córdoba, Argentine

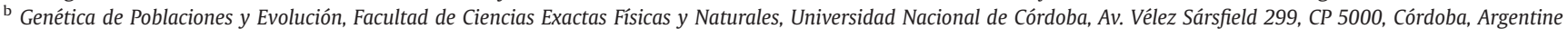 \\ c Alfred Wegener Institut für Polar und Meeresforschung, PO Box 120161, 27568 Bremerhaven, Germany
}

\section{A R T I C L E I N F O}

\section{Article history:}

Received 27 December 2007

Accepted 19 June 2008

\section{Keywords:}

Arctic

Ascidians

Genetic structure

\begin{abstract}
A B S T R A C T
The actual Arctic biota shows a strong affinity with that of the Boreal Atlantic and Pacific ones, as a result of an active recolonization process after the Quaternary glaciations. The geographic distribution of sessile species is usually linked to larvae dispersive capabilities which can be directly related with time spent in the plankton. Ascidians larvae are lecitothorphic and short-lived, which suggest that ascidians could be not efficient dispersers. However, the solitary ascidian Styela rustica (Linnaeus, 1767) (Tunicata, Ascidiacea) shows a wide distribution pattern from the North Atlantic to the Arctic that, together with the relatively recent colonization of the Arctic system could indicate that this species efficiently disperses and colonizes new habitats. In this study we used ISSR-PCR markers to study the genetic structure of five populations of the ascidian Styela rustica at Kongsfjorden, west Spitsbergen (Svalbard archipelago). We analyzed whether this species presents a low genetic structure, as can be expected due to the historical process of recent post glaciations colonization, or if there is genetic differentiation at a local scale, caused by short-lived larvae and limited dispersal potential. The genetic diversity in each population assessed using the marker diversity index (M) ranged from 0.288 to 0.324 . Population HN, situated close to a fast retreating glacier, showed the lowest diversity. Processes associated with deglatiation (icebergs calving from the glacier that scour the benthos and the increment of inorganic particulate matter on the water column) would drive to reduced population sizes and explain the reduced genetic variability observed in the HN population with respect to the others in the fjord. This suggests a possible linkage with the global warming process. Although the weak genetic structure found among the studied populations could indicate a founder effect, the genetic landscape shape analysis together with a positive relationship between genetic and geographic distances also suggest possible current gene flow among populations in the fjord.
\end{abstract}

(c) 2008 Elsevier B.V. All rights reserved.

\section{Introduction}

Shallow arctic shelves host a relative young marine assemblage which history reaches back some 15,000 years, due to the devastating effect the Quaternary glaciations had on these ecosystems. These events had occurred several times during the Quaternary and the last major one was that of Wisconsin, 18,000 years ago. At that time, sea level dropped down at least $85 \mathrm{~m}$ and almost all the actual Arctic Ocean was ice covered. These conditions drastically reduced most of the biological activity and almost eradicated the benthic fauna, which was disturbed as well by the impact caused by the huge amounts of sediments introduced into the ecosystem during the deglaciation process (Dunton, 1992; Piepenburg, 2005). The process of recolonization of the Arctic shelves has been active, and still is, during

\footnotetext{
* Corresponding author.

E-mail address: rsahade@efn.uncor.edu (R. Sahade).
}

the last 6,000 to 14,000 years, since deglaciation begun (Dayton et al., 1994; Weider and Hobæk, 2000). Therefore, the actual Arctic biota shows a strong affinity with that of the Boreal Pacific and mainly Atlantic ones and is characterized by low levels of endemism and lower biodiversity compared with temperate, tropical and also Antarctic ecosystems (Dayton, 1990; Dunton, 1992; Gray, 2001). The effects of the ice age are also reflected in the population genetic structure of species living in the Atlantic coasts, that show a gradient in genetic diversity in many species with increasing latitude and also showing the important role of glacial refugia (Hewitt, 2000; Coyer et al., 2003; Petit et al., 2003; Ben-Shlomo et al., 2006). It is possible to hypothesize that most of the species in the Arctic Ocean would present low genetic structure and low genetic diversity, but studies dealing with population genetic structure in benthic marine invertebrates in the Arctic are lacking so far.

Dispersion in the sea is thought to be facilitated by the homogeneous nature of the habitat, and many marine invertebrates are wide-ranging species with virtually continuous distributions. Species 
range may extend until a barrier stops the expansion, such as habitat suitability and oceanographic conditions like currents, salinity and temperature (Grosberg and Cunningham, 2001). The geographic distribution of sessile benthic species is usually linked to larvae dispersive capabilities, which can be directly related with time spent in the plankton. Then, species with long-lived planktonic larvae would exhibit more extended geographical distribution patterns and lower genetic structure (Cassista and Hart, 2007) than those species with short-lived or non planktonic larvae. However, the reverse situations have been reported: low genetic structure was found in groups with low dispersal potential as direct developers and short-lived pelagic larvae or high genetic structure in groups with planktonic larvae, situations that have been explained by local oceanographic conditions and/or particular reproductive or behavioral traits (Dias et al., 2006; Holmes et al., 2004; Imron, 2007; Kenchington et al., 2006; Kyle and Boulding, 2000; Marko, 2004). More striking patterns were also reported, where species with supposed limited dispersal potential exhibit low genetic differentiation over long spatial scales, but present locally structured populations (Casu et al., 2005; Ben-Shlomo et al., 2006; Yu and Chu, 2006).

Styela rustica (Linnaeus, 1767) (Tunicata, Ascidiacea) is a boreal-arctic solitary ascidian. As a filter-feeder, it depends on suspended organic matter. The free-living stage is a tadpole larva, capable of autonomous locomotion. Ascidians larvae are lecitothorphic and short-lived, which suggest that ascidians could be not efficient dispersers. However, S. rustica, as other ascidian species, shows a wide distribution range from the North Atlantic to the Arctic that, together with the relatively recent colonization of the Arctic system, could indicate that this species efficiently disperses and colonizes new habitats. This can be related to a longer larval period spent in the plankton than supposed, or a high generational turnover coupled with an efficient use of suitable habitats resulting in a rapid stepping stone process.

In this study we analyzed the genetic structure of the ascidian Styela rustica at Kongsfjorden, west Spitsbergen (Svalbard archipelago), using ISSR-PCR as molecular markers, in order to analyze whether it presents a low genetic structure, as can be expected due to the historical process of recent post glaciations colonization, or if locally a degree of genetic differentiation was established, caused by short-lived larvae and limited dispersal potential.

\section{Materials and methods}

\subsection{Study area}

Kongsfjorden is a $20 \mathrm{~km}$-long and 4 to $10 \mathrm{~km}$-wide high-latitude Arctic fjord in Spitsbergen that covers an area of $209 \mathrm{Km}^{2}$. It has a maximum depth of $350 \mathrm{~m}$ in the central part of the de fjord. Three glaciers, that discharge ice rafted materials in the fjord head, have been retreating several kilometres during the last 10-15 years. These glaciers are the most actively retreating ones in Svalbard archipelago (Svendsen et al., 2002; Wlodarska-Kowalczuk and Pearson, 2004).

\subsection{Sample collection}

Sampling of Styela rustica populations was carried out by SCUBA diving during the 2004 campaign in Koldewey-Station (Alfred Wegener Institut for Polar and Marine Research, Germany) in Kongsfjord, Spitsbergen $\left(78^{\circ} 55^{\prime} \mathrm{N}, 11^{\circ} 56^{\prime} \mathrm{E}\right)$. A total of 81 individuals were collected in five populations (putative status; Fig. 1); Prins Heinrichoya ( $\mathrm{PH}=25$ individuals), London (Lo=19 individuals), Hansneset $(\mathrm{HN}=10$ individuals) and Kongsfjordneset ( $\mathrm{KN}=11$ individuals) between 15 and $25 \mathrm{~m}$ depth, and Ny-Alesund Harbour (NA=16 individuals) between 3 and $8 \mathrm{~m}$ depth. Individuals were conserved in $80 \%$ ethanol until DNA extraction.

\subsection{Laboratory methods}

Genomic DNA was extracted from mantle (muscle) using the salt purification method described in protocol 1 of Bruford et al. (1992), and stored in aqueous solution at $-15^{\circ} \mathrm{C}$ until amplifications.

Genetic variability was assessed using inter-simple sequence repeats (ISSR-PCR) genetic markers. This technique is similar to

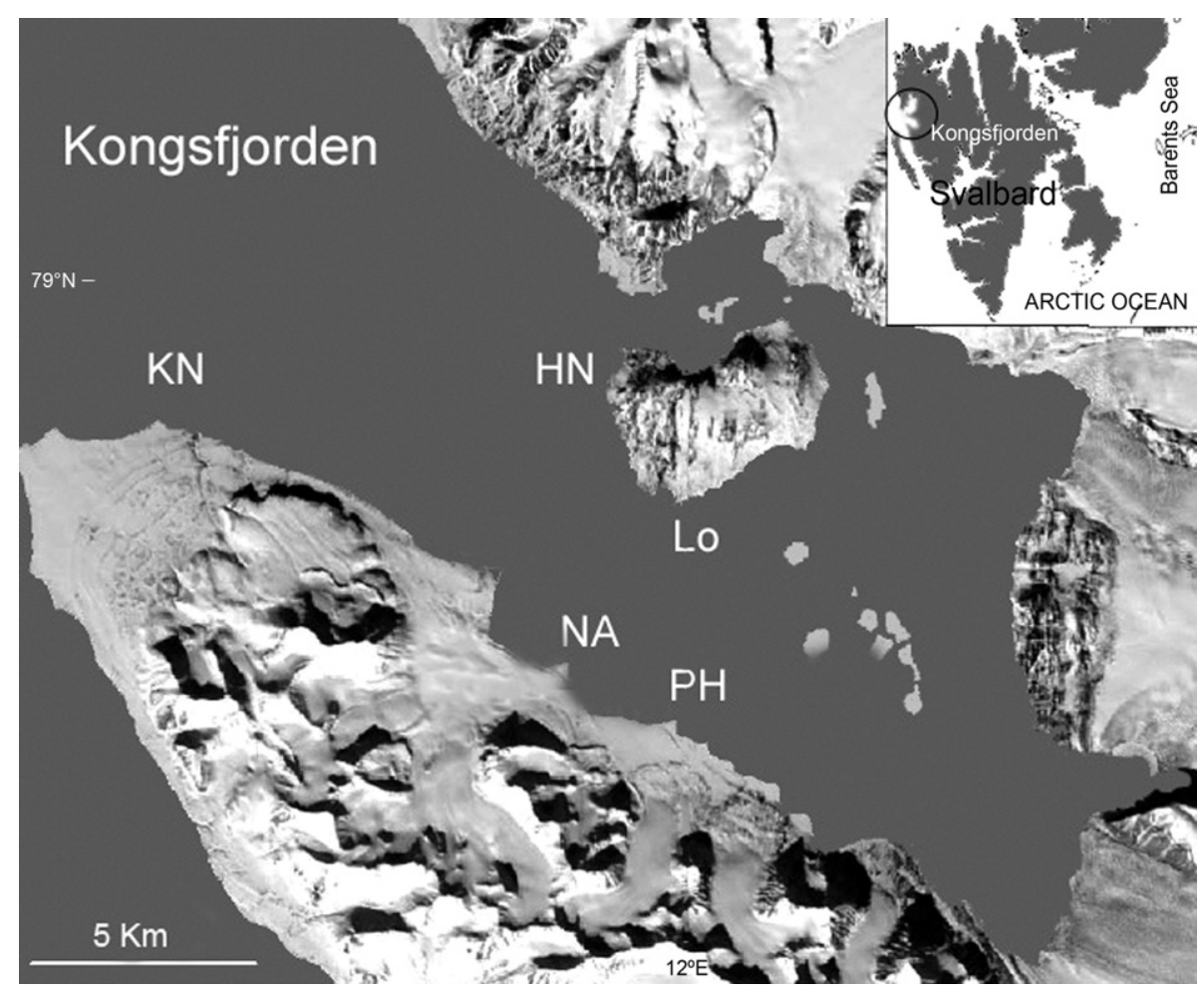

Fig. 1. Map and location of sampling sites in Kongsfjorden (Svalbard Archipelago). 
Table 1

Genetic diversity in five populations of Styela rustica from Kongsfjorden (Svalbard), estimated using the Marker diversity index (M)

\begin{tabular}{lll}
\hline Population & $\mathrm{M}$ & SNK Groups \\
\hline NA & 0.324 & $\mathrm{~A}$ \\
Lo & 0.309 & $\mathrm{AB}$ \\
PH & 0.307 & $\mathrm{AB}$ \\
KN & 0.304 & $\mathrm{AB}$ \\
HN & 0.288 & $\mathrm{~B}$ \\
\hline
\end{tabular}

Letters indicate the groups detected by Student-Newman-Keuls (SNK) multiple comparison procedure. Groups A and B indicate significant differences.

RAPDs, except that the ISSR primer consists of a di- or trinucleotide sequence repeat with a $5^{\prime}$ or $3^{\prime}$ anchoring sequence of 1 to 3 nucleotides. Primer sequence is also longer, allowing for a higher primer anneling temperature which results in greater band reproducibility than RAPD markers. The principle of ISSRs is that primer binding sites (microsatellite loci) are dispersed throughout the genome, so that there is a high chance that the primer binds to two sites located on opposing DNA strands within an amplifiable distance of one another. Thus, single-primer amplifications often result in a high degree of polymorphic bands, useful in population genetic studies. This technique does not require genome sequence information.

Each reaction volume contained 6 pmoles primer, $200 \mu \mathrm{M}$ dNTP, $1 \times$ Buffer (INVITROGEN $®$ ), $2,5 \mathrm{mM} \mathrm{MgCl}$, 0.2 U Taq DNA Polymerase (INVITROGEN®), $10 \mathrm{ng}$ DNA and sterile water up to $10 \mu \mathrm{l}$. Amplifications were carried out in an UNO II Biometra thermocycler. The thermocycling program consisted of an initial denaturation step of $94{ }^{\circ} \mathrm{C}$ for $2 \mathrm{~min}$, followed by 34 cycles of $30 \mathrm{~s}$ at $94{ }^{\circ} \mathrm{C}, 1 \mathrm{~min}$ at $48{ }^{\circ} \mathrm{C}$ and $1 \mathrm{~min} 30 \mathrm{~s}$ extension at $72^{\circ} \mathrm{C}$, followed by a final 5 min extension at $72{ }^{\circ} \mathrm{C}$. We tested 12 ISSR primers and 3 were chosen for the analysis due to its reproducibility and polymorphism: $5^{\prime}-(\mathrm{AC})_{10} \mathrm{AA}-3^{\prime} ; 5^{\prime}-$ $(A C)_{8} C-3^{\prime}$ and $5^{\prime}-(A G)_{8} Y^{\prime}-3^{\prime}$. Negative controls for each primer were included in the amplifications in order to detect bands caused by contamination. Amplification products were electrophoresed in $1 \mathrm{X}$ TBE buffer (0.045 M Tris Borate, $0.001 \mathrm{M}$ EDTA) on 1.5\% agarose gels stained with ethidium bromide, along with a $1 \mathrm{~Kb}$ ladder. Gels were run at $110 \mathrm{~V}$ for 5 hours. Band patterns were visualized with UV illumination and photographed.

\subsection{Data analysis}

Each ISSR band corresponds to a DNA sequence delimited by two inverted microsatellites. ISSR are diallelic markers, inherited in a dominant Mendelian fashion. The two possible phenotypes are: presence of a band (homozygote for the dominant allele or the heterozygote) and absence of a band (homozygote for the recessive allele). Allelic frequencies can be calculated only assuming HardyWeinberg equilibrium. As this information is not available for $S$. rustica, analyses that do not require converting band frequencies to allelic frequencies were performed.

A matrix of genetic distances between pairs of individuals (1-\% matching) was calculated from the matrix of presence/absence of bands with the program RAPDPLOT 3.0 (Black, 1995).

Genetic diversity estimates were obtained for each population according to Kapralov et al (2006). The proportion of unmatched ISSR bands between pairs of individuals within populations was averaged for each population to obtain the Marker Diversity Index (M), defined analogously to Nei's (1978) heterozygosity (Kapralov et al., 2006). One-way Analysis of variance (ANOVA) was used to compare the genetic diversity among populations, and Cochran $C$ test was used to check the homogeneity of variances. When means were different a Student-Newman-Keuls (SNK) multiple comparison procedure was used to identify which populations differed significantly.

The matrix of interindividual distances was used to perform an analysis of molecular variance (AMOVA), where total band variation was partitioned into a within populations and a between populations component. The level of differentiation between pairs of populations was calculated with the $\Phi_{\mathrm{ST}}$ index, an analogous to $\mathrm{F}_{\mathrm{ST}}$ (Wright, 1969) which is a measure of the variance in allelic frequencies (or band diversity, in this case) among populations. To test for significant deviation of between-groups variation from within-group variation, 1000 permutations were conducted to obtain a $p$ value. The program Arlequin 3.11 (Excoffier and Schneider, 2005) was used for these calculations.

Isolation by distance was tested by regression of the pairwise genetic differentiation and the pair-wise corresponding geographical distance between sampled populations. Geographic distance was measured as the shortest aquatic distance along the prevailing marine currents, and $\Phi_{\mathrm{ST}}$ between pairs of populations was used as genetic distance.

Since spatial distance is not the only factor depicting genetic patterns, but they are affected by the quality of a landscape as well (Holderegger and Wagner, 2006), a landscape-scale exploration analysis of patterns of genetic diversity and structure (genetic landscape shape) was performed using the program AIS (Miller, 2005 ) in order to detect the location of putative barriers or zones with low gene flow. This procedure allows the graphical representations of genetic distance patterns across landscape, through interpolation procedures of interindividual genetic distances.

\section{Results}

The three primers used revealed a total of 42 bands in the 81 individuals of $S$. rustica analysed, 38 bands were polymorphic and none was privative of populations. Primer $5^{\prime}-(\mathrm{AC})_{10} \mathrm{AA}-3^{\prime}$ amplified 18 bands; primer $5^{\prime}-(\mathrm{AC})_{8} \mathrm{C}-3^{\prime}$ amplified 15 bands and primer $5^{\prime}-(\mathrm{AG})_{8} \mathrm{Y}-3^{\prime}$ amplified 9 bands. The size of fragments ranged from 250 bp to $1,600 \mathrm{bp}$.

The genetic diversity in each population, assessed using the marker diversity index (M), ranged from 0.288 to 0.324 . The HN population, located in the middle of the fjord and very close to the Blomstrandbreen glacier, showed the lowest genetic diversity. The highest diversity was exhibited by NA population, which was sampled at the harbour wall of $\mathrm{Ny}$ Ålesund (Fig. 1), while the other 3 populations ( $\mathrm{PH}$, Lo and $\mathrm{KN}$ ) showed intermediate values of genetic diversity. Although slight, the differences were significant, and the SNK multiple comparison procedure indicated that the HN and NA populations were responsible for the statistical difference of genetic diversity (Table 1).

The AMOVA analysis showed that only $1.05 \%$ of total variation was due to differences among populations $\left(\Phi_{\mathrm{ST}}=0.011 ; \mathrm{p}>0.05\right)$; most of the variability resided within populations (98.95\%). However, when performed pair-wise the AMOVA analysis showed a statistically significant differentiation between $\mathrm{PH}$ and $\mathrm{HN}$ populations $\left(\Phi_{\mathrm{ST}}=0.034\right.$; $\mathrm{p}<0.001$ ) the differences between the other pairs examined were not statistically significant (Table 2 ).

The isolation by distance pattern was examined using pair-wise genetic differentiation $\left(\Phi_{\mathrm{ST}}\right.$ ) regressed against geographical distance, taken indirectly via the path of the prevailing currents. There was not a relationship between genetic and geographical distance $\left(r^{2}=0.08\right.$;

Table 2

Genetic differentiation between pairs of populations of S. rustica in Kongsfjorden

\begin{tabular}{llllll}
\hline Populations & PH & Lo & Pu & HN & KN \\
\hline PH & - & 0.248 & 0.258 & $<\mathbf{0 . 0 5}$ & 0.434 \\
Lo & 0.007 & - & 0.339 & 0.498 & 0.112 \\
Pu & 0.007 & 0.008 & - & 0.304 & 0.221 \\
HN & $\mathbf{0 . 0 3 4}$ & 0.003 & 0.003 & - & 0.355 \\
KN & 0.002 & 0.014 & 0.015 & 0.019 & -
\end{tabular}

Pair-wise $\Phi_{\mathrm{ST}}$ values are shown below the diagonal, $\mathrm{p}$ values are above the diagonal. 
a)

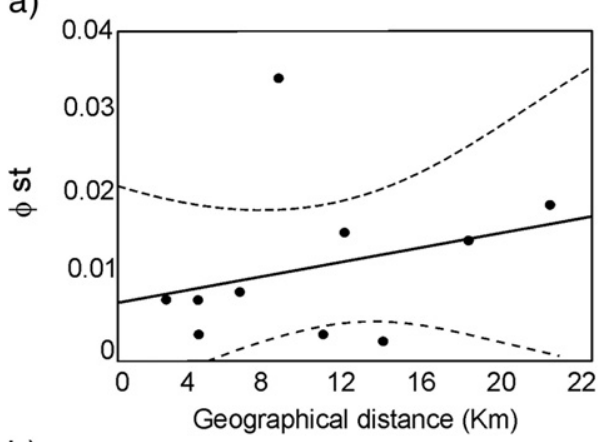

b)

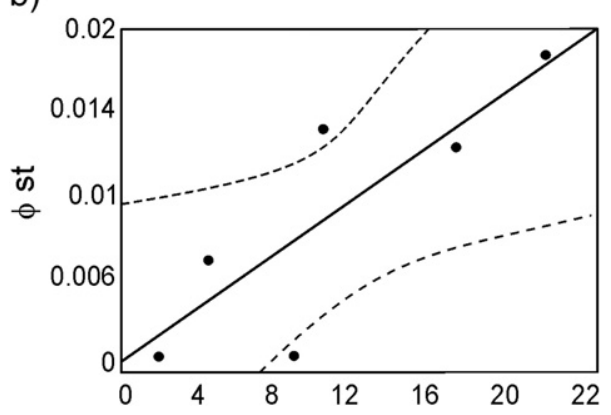

Fig. 2. Regressions of Styela rustica pair-wise geographic distances (in $\mathrm{Km}$ ) and $\Phi_{\mathrm{ST}}$ values. a) Pair-wise distances among the five populations. b) Pair-wise distances excluding $\mathrm{PH}$ population.

$\mathrm{F}=0.71 ; \mathrm{p}>0.05$ ) (Fig. 2a). However, if $\mathrm{PH}$ population is excluded, a positive relationship between genetic and geographic distances is exhibited $\left(r^{2}=0.69 ; \mathrm{F}=9.02 ; \mathrm{p}<0.05\right)$ (Fig. 2b).

The genetic landscape shape analysis, that allows the graphical representation of genetic distance patterns across landscape through interpolation procedures of interindividual genetic distances, indicated a probable important barrier to gene flow located at the middle of the fjord, where the maximum depths are present $(>300 \mathrm{~m})$. Other minor peaks are present at the inner fjord (Fig. 3).

\section{Discussion}

Genetic data demonstrated to be very useful to infer and to increase the actual understanding about the possible processes that lead to the Arctic colonization and ecosystem functioning after the last Quaternary glaciations, moreover when fossil record is lacking (Hewitt, 1996, 2000; Widmer and Lexer, 2001; Marko, 2004). A growing interest on population genetic structure surveys at different scales in the Arctic has been evident in the last decade. Most of the work in the marine realm was devoted to fishes and mammals (Wilson et al., 1996; Brown-Gladden et al., 1997; Paetkau et al., 1999; Weider and Hobæk, 2000, and others). Terrestrial plants, invertebrates, birds and mammals have been the focus of several works as well (Tollefsrud et al., 1998; Holder et al., 1999; Ehrich et al., 2000). However, this is the first work, at least to our knowledge, dealing with the population genetic structure of a benthic marine faunal organism in the high Arctic, and using ISSR-PCR markers that just recently have been used in marine species (Casu et al., 2007; Hou et al., 2006; Maltagliati et al., 2006; Lewallen et al., 2007; Varela et al., 2007).

\subsection{Genetic Diversity}

Low genetic diversity would be an expected pattern for most Arctic species as a result of the recent range expansion from southern ecosystems, of bottleneck effects on the remaining glacial refugia during the glaciations and of the posterior founder episodes from these centers when deglaciation begun (Hewitt, 2003). Consistently, a clear genetic diversity cline along a latitudinal gradient resembling ice expansion is shown by several species with some high latitude hotspots that would indicate the position of those ice free areas that harboured surviving populations (Coyer et al., 2003; Gysels et al., 2004; Provan et al., 2005; Ben-Shlomo et al., 2006). The genetic diversity found in $S$. rustica was similar to that exhibited by an Antarctic ascidian species Aplidium falklandikum (Demarchi unpub data). Due to the evolutionary history and stability of the Antarctic ecosystem, genetic diversity is supossed to be higher than in comparable species in the Arctic. This suggest that either, $S$ rustica shows a higher than expected diversity that could be related to the proximity of a glacial refugium or A. falklandikum has a lowered genetic diversity.

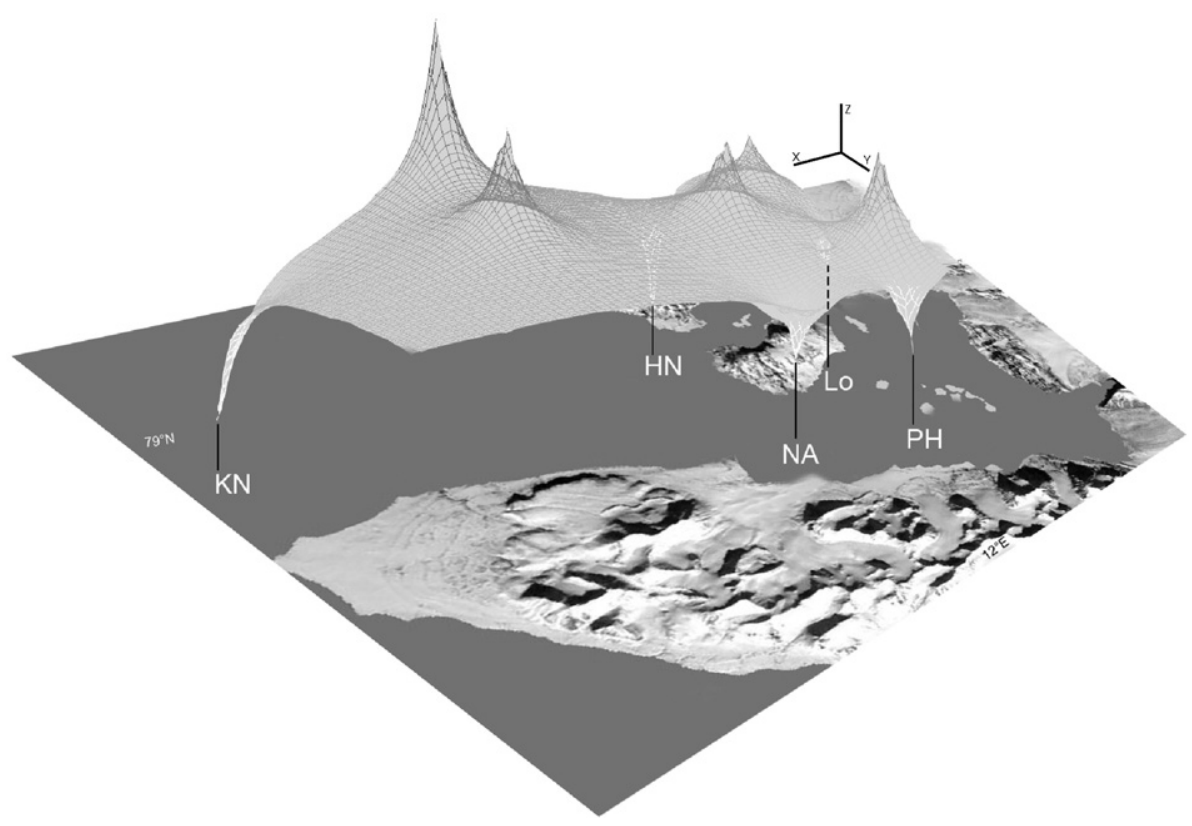

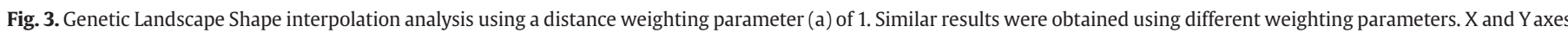
correspond to geographic locations; genetic distances are on the $\mathrm{Z}$ axis. Positive peaks show genetic discontinuities or possible barriers to gene flow. 
Data of Southern populations of S. rustica will be useful to answer this question.

At a local scale, the five populations of Styela rustica surveyed showed significant differences in genetic diversity: HN and NA populations showed the lowest and highest diversities respectively, while the other three populations showed intermediate values. Besides the historical processes previously discussed, current ecological processes can also affect the genetic variability of local populations. In the present case, $\mathrm{HN}$ population is situated close to the Bloomstrandbreen glacier, which has been retreating at a rate of $35 \mathrm{~m}$ per year being one of the most actively retreating glaciers in Svalbard (Svendsen et al., 2002). Besides the direct effect of icebergs and growlers calving from the glacier that scour the benthos causing a significant physical disturbance (Gutt and Starmans, 2001), the increment of inorganic particulate matter on the water column could also play a very important role affecting benthic communities. The amount of organic carbon available for organisms, especially filter feeders like ascidians, can be severely reduced and in an extreme case the sedimentation of inorganic particles may cause filter-feeder's gills clogging (Fetzer et al., 2002). Since these processes would directly affect the population fitness and even increase mortality rates, leading to reduced population sizes, they could explain the reduced genetic variability observed in the $\mathrm{HN}$ population with respect to the others in the fjord. Similarly, suspended matter and sedimentation in Arctic fjords has been considered as the principal disturbance factor reducing diversity in benthic communities (Weslawski et al., 1999; Wlodarska-Kowalczuk et al., 2005). Taking into account that the Arctic region, together with the West Antarctic Peninsula, is where the climate change is taking place faster (while the mean global temperature increase in the last 50 years was around $0.6{ }^{\circ} \mathrm{C}$, in these polar areas it was around $2{ }^{\circ} \mathrm{C}$, Vaughan et al., 2001), and glacier retreat can be a consequence of the global warming, then our results could be related to that process. On the other hand, the high diversity registered in the NA population was striking given the reduced habitat available:, it is confined to a wall of $50 \times 8 \mathrm{~m}$ in the harbour of $\mathrm{Ny}$ Ålesund. In contrast, at all the other sites (with the exception of HN that will be discussed further) the available habitat without evident discontinuities comprised several hundreds of meters horizontally, and vertically at least to the dived depths of ca. $35 \mathrm{~m}$. However, the harbour of Ny Ålesund suports in summer time an intense traffic of ships that could introduce new colonizers, increasing the genetic diversity of the population.

\subsection{Differentiation among populations}

When analysed together, no genetic differentiation was detected among the five populations of $S$. rustica studied. However, in the pairwise analysis a significant differentiation was observed between $\mathrm{HN}$ and $\mathrm{PH}$ populations. This suggests that the difference could be slight and then hindered in the global test. Although these results are in line with the expectations, it is not possible to asseverate that the weak structure observed is a signature of the last glaciations and recent colonization. Since the present genetic structure of a species is the result of historical and current processes, and the used technique does not allow differentiating between them (Bossart and Pashley-Prowell, 1998; Grosberg and Cunningham, 2001); it could be also possible that high current gene flow between these populations cause the genetic homogeneity in Kongsfjorden. Solitary ascidians as S. rustica are typically broadcast spawners with lecithotrophic larvae which last in average $12 \mathrm{~h}$ in the plankton, and in some cases up to 1 week (Svane and Young 1989; Burighel and Cloney, 1997), suggesting limited dispersal potential. However other solitary ascidian, Pyura gibbosa, showed no genetic differentiation over a scale of $215 \mathrm{~km}$. Whereas colonial species, which are usually brooders with shorter free larval periods exhibit genetic structure even at scales of meters or tens of meters (Ayre et al 1997), including the species Botrillus schlosseri one of the most successful colonizer and invader species which also shows the influence of the glaciations on their genetic structure along the European coasts (Yund and O'Neil, 2000; Ben-Shlomo et al., 2001, 2006; Stoner et al., 2002). Similarly other taxa as bivalves, corals and bryozoans with lecithotrophic or aplanic larvae show significant genetic variation on scales from tens of meters to few kilometres (Goldson et al., 2001; Holmes et al., 2004). Therefore, although perfectly possible that at the studied scale in Kongsfjoden of ca $20 \mathrm{~km}$ the populations of S. rustica are under an active gene flow causing the observed genetic structure it is not possible to asseverate that either.

In order to analyze which of the hypothesized processes, founder effect or current larval exchange, is more likely responsible for the weak structure found, isolation by distance patterns and genetic landscape shape were analyzed. When all populations where included, no isolation by distance pattern was detected. But if $\mathrm{PH}$ population is excluded from the analyses, a strong positive pattern of isolation by distance along the prevailing currents in the fjord is showed. This would suggest a current degree of gene flow on the fjord. But why the PH population is excluded from this pattern? A likely explanation can be related to the fact that this population, contrary to all the others, is established in an area dominated by soft bottoms, interspersed with small rocks and boulders conforming a mosaic pattern of small islands of suitable habitat where individuals of $S$. rustica are settled, which are isolated from the other populations by the depths in the middle fjord and by soft substrata with those in the same coast. This could suggest that the similarity with the other populations can be due to a founder effect and can also explain the difference with the HN population which diversity was significantly reduced if, by chance, the lost alleles had been those shared with $\mathrm{PH}$ population.

The genetic landscape shape analysis is indicating that the middle fjord zone can be considered as important barrier to the gene flow; it shows an unusual high genetic disconitinuity which coincides with depths of more than $300 \mathrm{~m}$ that are below the bathymetric range of $S$. rustica (Van Name, 1945). This is consistent with the oceanography of Kongsfjorden; the circulation of the water inside the fjord is dominated by tidal currents that go along lateral boundaries, coastlines (Svendsen et al., 2002), so larval transport may be facilitated by currents moving parallel to the coast. This would suggest that the connection between populations on the same coast can be realized via a stepping-stone process in suitable habitats and direct transport of larvae to the opposite coast.

In conclusion, the isolation by distance model, with the exception of $\mathrm{PH}$, and the genetic landscape analysis suggest a current larval exchange, since a founder effect in the postglacial period with sporadic or no posterior gene flow would had produced a more chaotic pattern, mainly driven by genetic drift and inbreeding.

\section{Acknowledgements}

We thank the members of Koldewey Station (2004) for their assistance, especially to our dive companions Saskiachen Brandt, Danielito Carstensen, Felipito Schubert and Kleine Nik Probst. Financial and logistic supports were provided by Alfred Wegener Institut, BMBF-SECyT and.CONICET. This work has been made in the context of a $\mathrm{PhD}$ in the Universidad Nacional de Córdoba, Argentina. [SS]

\section{References}

Ayre, D.J., Davis, A.R., Billingham, M., Llorens, T., Styan, C., 1997. Genetic evidence for contrasting patterns of dispersal in solitary and colonial ascidians. Mar. Biol.130, 51-61.

Ben-Shlomo, R., Douek, J., Rinkevich, B., 2001. Heterozygote and chimerism in remote populations of a colonial ascidian from New Zealand. Mar. Ecol. Prog. Ser. 209,109-117.

Ben-Shlomo, R., Paz, G., Rinkevich, B., 2006. Postglacial-period and Recent Invasions Shape the Population Genetics of Botryllid Ascidians along European Atlantic Coasts. Ecosystems 9, 1118-1127. 
Black, B., 1995. FORTRAN programs for the analysis of RAPD-PCR data. wcb4@lamar. colostate.edu.

Bossart, J.L., Prowell, D.P., 1998. Genetic estimates of population structure and gene flow: Limitations, lessons and new directions. Trends Ecol. Evol. 13, 202-206.

Brown-Gladden, J.G., Ferguson, M.M., Clayton, J.W., 1997. Matriarchal genetic population structure of North American beluga whales Delphinapterus leucas (Cetacea: Monodontidae). Mol. Ecol. 6, 1033-1046.

Bruford, M.E., Hanotte, O., Brookfield, J.F.Y., Burke, T., 1992. Single-locus and multilocus DNA fingerprinting. In: Hoelzel, A.R. (Ed.), Molecular Genetic Analysis of Populations, A Practical Approach. Oxford University Press, p. 228.

Burighel, P., Cloney, R.A., 1997. Urochordata: Ascidiacea. In: Harrison, F.W., Ruppert, E.E. (Eds.), Microscopic anatomy of invertebrates, vol. 15. Wiley-Liss, New York, pp. 221-347.

Cassista, M.C., Hart, M.W., 2007. Spatial and temporal genetic homogeneity in the Arctic surfclam (Mactromeris polynyma). Mar. Biol. 152, 569-579.

Casu, M., Maltagliati, F., Cossu, P., Lai, T., Galletti, M.C., Castelli, A., Commito, J.A., 2005. Fine-grained spatial genetic structure in the bivalve Gemma gemma from Maine and Virginia (USA), as revealed by Inter-Simple Sequence Repeat markers. J. Exp. Mar. Biol. Ecol. 325, 46-54.

Casu, M., Casu, D., Lai, T., Cossu, P., Curini-Galletti, M., 2007. A molecular tool for genetic surveys in the red coral (Corallium rubrum): An Inter-Simple Sequence Repeats (ISSRs) perspective. Biochem. Syst. Ecol. doi:10.1016/j.bse.2007.08.011.

Coyer, J.A., Peters, A.F., Stam, W.T., Olsen, J.L., 2003. Post-ice age recolonization and differentiation of Fucus serratus L. (Phaeophyceae; Fucaceae) populations in Northern Europe. Mol. Ecol. 12 (7), 1817-1829.

Dayton, P.K., 1990. Polar benthos. In: Smith, W.E. (Ed.), Polar Oceanography, part B: Chemistry, Biology and Geology. Academic Press, London, pp. 631-685.

Dayton, P.K., Mordida, B.J., Bacon, F., 1994. Polar marine communities. Am. Zool. 34, 90-99.

Dias, M.G., Duarte, L.F.L., Solferini, V.N., 2006. Low genetic differentiation between isolated populations of the colonial ascidian Symplegma rubra Monniot, C. 1972. Mar. Biol. 148, 807-815.

Dunton, K., 1992. Arctic biogeography: The paradox of the marine benthic fauna and flora. Trends Ecol. Evol. 7 (6), 183-189.

Excoffier, L.G.L., Schneider, S., 2005. Arlequin ver. 3.0: An integrated software package for population genetics data analysis. Evol. Bioinformatics Online 1,47-50.

Ehrich, D., Fedorov, V.B., Stenseth, N.C., Krebs, C.J., Kenney, A., 2000. Phylogeography and mitochondrial DNA (mtDNA) diversity in North American collared lemmings (Dicrostonyx groenlandicus). Mol. Ecol. 9, 329-337.

Fetzer, I., Lønne, O.J., Pearson, T., 2002. The distribution of juvenile benthic invertebraes in an arctic glacial fjord. Polar Biol. 25, 303-315.

Goldson, A.J., Hughes, R.N., Gliddon, C.J., 2001. Population genetic consequences of larval dispersal mode and hydrography: A case study with bryozoans. Mar. Biol.138, 1037-1042.

Gray, J.S., 2001. Marine diversity: The paradigms in patterns of species richness examined. Sci. Mar. 65 (2), 41-56.

Grosberg, R., Cunningham, C.W., 2001. Genetic structure in the sea from populations to communities. In: Bertness, M.D., Gaines, S., Hay, M.E. (Eds.), Marine Community Ecology. Sinauer Associates, Sunderland, M. A., pp. 61-84.

Gutt, J., Starmans, A., 2001. Quantification of iceberg impact and benthic recolonization patterns in the Weddell Sea (Antarctica). Polar Biol. 24, 615-619.

Gysels, E.S., Hellemans, B., Pampouli, C., Volckaert, F.A.M., 2004. Phylogeography of the common goby, Pomatoschistus microps, with particular emphasis on the colonization of the Mediterranean and the North Sea. Mol. Ecol. 13, 403-417.

Hewitt, G.M., 1996. Some genetic consequences of ice ages, and their role in divergence and speciation. Biol. J. Linn. Soc. 58, 247-276.

Hewitt, G., 2000. The genetic legacy of the Quaternary ice ages. Nature 405, 907-913.

Hewitt, G.M., 2003. A climate for colonization. Heredity 1-2.

Holderegger, R., Wagner, H.H., 2006. A brief guide to Landscape Genetics. Landsc. Ecol. 21, 793-796

Holder, K., Montgomerie, R., Friesen, V.L., 1999. A test of the glacial refugium hypohtesis using patterns of mitochondrial and nuclear DNA sequence variation in rock ptarmigan (Lagopus mutus). Evolution 53, 1936-1950.

Holmes, S.P., Dekker, R., Williams, I.D., 2004. Populations dynamics and genetic differentiation in the bivalve mollusc Abra tenuis: aplanic dispersal. Mar. Ecol. Prog. Ser. 268, 131-140.

Hou, L., Lü, H., Zou, X., Xiangdong, B., Yan, D., He, C., 2006. Genetic characterizations of Mactra veneriformis (Bivalve) along the Chinese coast using ISSR-PCR markers. Aquaculture 261, 865-871.

Imron, Jeffrey, B., Hale, P., Degnan, B.M., Degnan, S.M., 2007. Pleistocene isolation and recent gene flow in Haliotis asinina, an Indo-pacific vetigastropod with limited dispersal capacity. Mol. Ecol. 16, 289-304.
Kapralov, M.V., Gabrielsen, T.M., Sarapultsev, I.E., Brochmann, C., 2006. Genetic enrichment of the arctic clonal plant Saxifraga cernua at its southern periphery via the alpine sexual Saxifraga sibirica. Mol. Ecol. 15, 3401-3411.

Kenchington, E.L., Patwary, M.U., Zouros, E., Bird, C.J., 2006. Genetic differenciation in relation to marine landscape in a broadcast-spawning bivalve (Placopecten magellanicus). Mol. Ecol. 15, 1781-1796.

Kyle, C.J., Boulding, E.G., 2000. Comparative population genetic structure of marine gastropods (Littorina spp.) with and without pelagic larval dispersal. Mar. Biol. 139, 835-845.

Lewallen, E.A., Anderson, T.W., Bohonak, A.J., 2007. Genetic structure of leopard shark (Triakis semifasciata) populations in California waters. Mar. Biol. 152, 599-609.

Maltagliati, F., Lai, T., Casu, M., Valdesalici, S., Castelli, A., 2006. Identification of endangered Mediterranean cyprinodontiformfish by means of DNA inter-simple sequence repeats (ISSRs). Biochem. Syst. Ecol. 34, 626-634.

Marko, P.B., 2004. What's larvae got to do with it?' Disparate patterns of post-glacia population structure in two benthic marine gastropods with identical dispersal potential. Mol. Ecol. 13, 597-611.

Miller, M.P., 2005. Alleles In Space: Computer software for the joint analysis of interindividual spatial and genetic information. J. Heredity 96, 722-724.

Nei, M., 1978. Estimation of average heterozygosity and genetic distance from a small number of individuals. Genetics 89, 583-590.

Petit, R.J., Aguinagalde, I., De Beaulieu, J.L., Bittkau, C., Brewer, S., Cheddadi, R., Ennos, R., Fineschi, S., Grivet, D., Lascoux, M., Mohanty, A., Müller-Starck, G., DemesureMusch, B., Palmé, A., Martín, J.P., Rendell, S., Vendramin, G.G., 2003. Glacial refugia: Hotspots but not melting pots of genetic diversity. Science 300, 1563-1565.

Paetkau, D., Amstrup, S.C., Born, E.W., Calvert, W., Derocher, A.E., Garner, G.W., Messsier F., Stirling, I., Taylor, M.K., Wiig, Ø., Strobeck, C., 1999. Genetic structure of the world's polar bear populations. Mol. Ecol. 8, 1571-1584.

Piepenburg, D., 2005. Recent research on Arctic benthos: Common notions need to be revised. Polar Biol. 28, 733-755.

Provan, J., Wattier, R.A., Maggs, C.A., 2005. Phylogeographic analysis of the red seaweed Palmari palmate reveals a Pleistocene marine glacial refugium in the English Channel. Mol. Ecol. 14, 793-803.

Stoner, D.S., Ben-Schlomo, R., Rinkevich, B., Weissman, I.V., 2002. Genetic variability of Botryllus schlosseri invasions to the east and west coasts of the USA. Mar. Ecol. Prog. Ser. 243, 93-100.

Svane, I., Young, C.M., 1989. The ecology and behaviour of ascidian larvae. Oceanogr Mar. Biol. Annu. Rev. 27, 45-90.

Svendsen, H., Beszczynska-Møller, A., Hagen, J.O., Lefauconnier, B., Tverberg, V., Gerland, S Ørbæk, J.B., Bischof, K., Papucci, C., Zajaczkowski, M., Azzolini, R., Bruland, O., Wiencke, C., Winther, J.-G., Dallmann, W., 2002. The physical environment of KongsfjordenKrossfjorden, an Arctic fjord system in Svalbard. Polar Res. 21, 133-166.

Tollefsrud, M.M., Bachmann, K., Jakobsen, K.S., Brochman, C., 1998. Glacial survival does not matter. II: RAPD phylogoegraphy of Nordic Saxifraga cespitosa. Mol. Ecol. 7, 1217-1232.

Van Name, W.G., 1945. The North and South American ascidians. Bull. Am. Mus. Nat. Hist. 84, 1-476.

Varela, M.A., González-Tizón, A., Mariñas, L., Martínez-Lage, A., 2007. Genetic Divergence Detected by ISSR Markers and Characterization of Microsatellite Regions in Mytilus Mussels. Biochem. Genet. 45, 565-578.

Vaughan, D.G., Marshall, G.J., Connolley, W.M., King, J.C., Mulvaney, R., 2001. Devil in the Detail. Science 293, 1777-1779.

Weider, L.J., Hobæk, A., 2000. Phylogeography and arctic biodiversity: A review. Ann. Zool. Fenn. 37, 217-231.

Weslawski, J.M., Szymelfenig, M., Zajaczkowski, M., Keck, A., 1999. Influence of salinity and suspended matter on benthos of an Arctic tidal flat. J. Mar. Sci. 56, 194-202.

Widmer, A., Lexer, C., 2001. Glacial refugia: sancturaries for allelic richness, but not for gene diversity. Trends Ecol. Evol. 16 (6), 267-269.

Wilson, C.C., Hebert, P.D.N., Reist, J.D., Dempson, J.B., 1996. Phylogeography and postglacial dispersal of arctic charr Salvelinus alpinus in North America. Mol. Ecol. 5, 187-197.

Wlodarska-Kowalczuk, M., Pearson, T.H., 2004. Soft-bottom macrobenthic faunal associations and factors affecting species distributions in an Arctic glacial fjord (Kongsfjord, Spitsbergen). Polar Biol. 27, 155-167.

Wlodarska-Kowalczuk, M., Pearson, T.H., Kendall, M.A., 2005. Benthic response to chronic natural physical disturbance by glacial sedimentation in an Arctic fjord MEPS 303, 31-41.

Wright, S., 1969. Evolution and the genetics of populations. The theory of gene frequencies, Vol. 2. Univ. of Chicago Press, Chicago, IL.

Yu, D.H., Chu, K.H., 2006. Low genetic differentiation among widely separated populations of the pearl oyster Pinctada fucata as revealed by AFLP. J. Exp. Mar. Biol. Ecol. 333, 140-146.

Yund, P.O., O'Neil, P.G., 2000. Microgeographic genetic differentiation in a colonial ascidian (Botryllus schlosseri) population. Mar. Biol. 137, 583-588. 